\title{
Pkm Pemanfaatan Botol dan Kardus Bekas dalam Pembuatan Alat Peraga Edukatif (Ape) di Gugus PAUD 10 Kecamatan Kanigaran Probolinggo
}

\section{Utilization of Used Bottles and Cartons in the Development of Educational Teaching Aids (APE) in PAUD Cluster 10 Kanigaran, Probolinggo District}

\author{
Darwin Djeni ${ }^{1)}$ Eko Waluyo $^{2)}$ Vivin Agustin Anggraini ${ }^{3)}$ Loviga Denny Pratama ${ }^{4)}$ \\ Email : 'darwindjeni49.inzah@gmail.com; ${ }^{1}$ ekowaluyo.inzah.tdm@ gmail.com ; \\ ${ }^{3}$ vivinagustinanggraini.inzah@gmail.com; ${ }^{4}$ loviga.pratama@gmail.com \\ ${ }^{1,2,3,4} \mathrm{INZAH}$ Genggong Probolinggo
}

\begin{abstract}
The aim and target to be achieved in this community service program is to conduct training in making educational aids for PAUD and kindergarten teachers in Kecamatan Kanigaran Probolinggo City so that they can utilize used goods (bottles and cardboard) as educational aids. Outputs generated from this community service program are educational aids Products and Journal Publications. The making of educational aids by teachers aims at improving teachers creativity and innovation, reducing the amount of used gods and lowering the school expenses. Partners of this program play a role in preparing materials, conducting activities and evaluating to activities and continuing to develop other educational products. The sustainability of this program results in creative and innovative early childhood and kindergarten teachers, minimizing the amount of used goods and minimizing the find of producing educational products.
\end{abstract}

Keywords: APE, Creativity, PAUD.

\begin{abstract}
Abstrak: Tujuan dan sasaran yang ingin dicapai dalam proposal PKM adalah mengadakan pelatihan membuat APE untuk guru PAUD dan TK di Kecamatan Kanigaran Kota Probolinggo sehingga mereka dapat memanfaatkan barang bekas (botol dan kardus) untuk APE. Output yang dihasilkan dari program PKM adalah Produk APE dan Publikasi Jurnal. Guru akan menjadi kreatif dan inovatif, menggunakan barang bekas dan mengurangi dana sekolah. Publikasi jurnal yang ditujukan untuk hasil PKM ini dapat menjadi bahan literasi untuk guru PAUD-TK dan pihak lain. Mitra berperan dalam menyiapkan bahan, melakukan kegiatan, dan mengevaluasi kegiatan PKM dan berkomitmen untuk melanjutkan kegiatan PKM dan mengembangkan produk APE lainnya. Keberlanjutan program ini menghasilkan guru PAUD dan TK yang kreatif dan inovatif, meminimalkan jumlah barang bekas dan pembiayaan APE.
\end{abstract}

Kata kunci: APE, Kreativitas, PAUD.

\section{PENDAHULUAN}

Pendidikan anak usia dini (PAUD) dan taman kanak-kanak (TK) adalah jenjang pendidikan sebelum jenjang pendidikan dasar yang dimaksudkan sebagai 


\section{INTEGRITAS : Jurnal Pengabdian}

Vol 3, No 1, Juli 2019

ISSN 2580-7978 (Cetak) ISSN 2615-0794 (Online)

upaya pembinaan anak sejak lahir sampai dengan usia enam tahun. Proses pendidikan yang dilakukan melalui pemberian rangsangan pendidikan untuk membantu pertumbuhan dan perkembangan jasmani dan rohani agar anak memiliki kesiapan dalam memasuki pendidikan dasar. Pendidikan anak usia dini merupakan salah satu bentuk penyelenggaraan pendidikan yang menitikberatkan pada peletakan dasar ke arah pertumbuhan dan 6 (enam) perkembangan: agama dan moral, fisik motorik, kognitif, bahasa, sosial-emosional, dan seni, sesuai dengan keunikan dan tahap-tahap perkembangan sesuai kelompok usia yang dilalui oleh anak usia dini seperti yang tercantum dalam Permendikbud 137 tahun 2014 tentang Standar Nasional PAUD (menggantikan Permendiknas 58 tahun 2009).

Suasana pembelajaran PAUD dan TK bersifat sederhana, menarik dan menyenangkan, karena itu nilai-nilai perkembangan anak ditanamkan melalui kegiatan permainan. Dengan kata lain, kegiatan pembelajaran PAUD dan TK memerlukan media ajar seperti sound set, pemainan anak maupun alat peraga edukatif (APE). Media ajar berfungsi sebagai objek ajar/ alat bantu ajar visual, lisan, sikap maupun pendengaran, sedangkan guru menjadi pendamping dan pengarah (fasilitator) anak-anak. Semakin menarik dan bagus media ajar maka ketertarikan anak bermain dan belajar semakin besar.Namun tidak semua PAUD dan TK mempunyai media ajar yang variatif, karena untuk pengadaan media ajar PAUD dan TK biaya relatif mahal, salah satunya pengadaan APE.

PAUD dan TK selama ini masih bersifat konsumtif dalam pembelian media ajar APE. Hal ini berdampak biaya belanja sekolah, sehingga akan berdampak pada biaya anak di PAUD/ TK tersebut. Oleh karena itu, Guru PAUD dan TK dituntut kreatif dan inovasi dalam hal mealakukan kegiatan pembelajaran, salah satunya pembuatan APE sehingga dapat meningkatkan ketrampilan, kreatifitas guru.Namun pembuatan APE dengan bahan bagus dan berkualitas membutuhkan biaya yang relatif mahal sehingga diperlukan bahan alternatif yang bersifat ekonomis yakni barang bekas seperti botol bekas, kardus, dan lainnya.Hal ini 


\section{INTEGRITAS : Jurnal Pengabdian}

Vol 3, No 1, Juli 2019

ISSN 2580-7978 (Cetak) ISSN 2615-0794 (Online)

berarti, guru dituntut membuat APE dengan biaya ekonomi yakni menggunakan barang bekas.

Mitra dalam PKM ini adalah Guru PAUD-TK Gugus 10 PAUD Kecamatan Kanigaran dengan jarak lokasi dari kampus INZAH berkisar $25 \mathrm{~km}$. Gugus 10 PAUD Kecamatan Kanigaran merupakan media komunikasi dan sharing guru PAUD dan TK terkait pembelajaran, media ajar, manajerial dan lainnya. Gugus

10 PAUD kecamatan Kanigaran terdiri dari PAUD Taman Indria 2, RA Al Hikmah, KB Mandiri, TPA Fajar Arry Mulia, TK Mustika BUnda, TK Tunas Bakti, dan TK Muhasabah,. Adapun beberapa permasalahan mitra pengabdian adalah sebagai berikut.

1. Pengadaan APE masih bersifatkonsumtif ?

2. Upaya peningkatan kreatifitas dan inovasi guru terhadap pembelajaran?

3. Kontribusi terhadap lingkungan hidup terkait barang bekas (Botol dan Kardus).

Berdasarkan latar belakang tersebut, kegitan pengabdian berupa pelatihan pemanfaatan barang bekas yakni botol dan kardus menjadi alat peraga edukatif.Adapun APE yang dimaksud adalah mengenal huruf abjad dan angka serta huruf dan angka hijaiyah.

\section{METODE PELAKSANAAN}

Metode yang digunakan dalam pengabdian ini adalah pendampingan pembuatan APE. Pendampingan yang dimaksud adalah mendampingi mitra menyelesaikan permasalahn ini yakni pengadaan APE yang ekonomis dan peningkatkan kreatifitas dan inovatif guru PAUD dan TK Gugus 10 Kecamatan Kanigaran Kota Probolinggo. Adapun partisipasi mitra pada program ini juga melibatkan wali murid dalam menyediakan bahan utama pengabdian yakni kardus dan botol mineral bekas.Keberlanjutan program ini kedepan adalah munculnya APE lainnya dari kreatifitas guru. Selain itu, Tadris Matematika dengan Gugus 10 PAUD dan TK Kecaatan Kanigaran bisa membuat MoU kerjasama yakni Tadris Matematika menjadi nara sumber ahli dan mitra menjadi objek pengabdian. 


\section{INTEGRITAS : Jurnal Pengabdian}

Adapun luaran yang diharapkan adalah: 1) Produk APE yang menarik 2) Peningkatan kualitas guru 3). Publikasi/ Jurnal 4) Buku panduan membuat APE huruf alfabet dan huruf hijaiyah.

\section{HASIL DAN LUARAN}

Dalam proses pelaksanaan kegiatan PKM ini dibagi menjadi 4 Tahapan yaitu;

\section{Tahap Observasi}

Dalam tahap ini yang dilakukan adalah permohonan ijin melakukan pengabdian, identifikasi permasalahan pengabdian yakni jumlah APE yang kurang di setiap institusi, upaya membuat APE sendiri tapi terkendala ide dan biaya, dan upaya peningkatan inovasi pembelajaran.

\section{Tahap Persiapan}

Dalam tahap ini, mempersiapkan alat dan bahan.Bahan utama adalah kardus bekas dan botol air mineral bekas.Bahan ini didapat dari setiap wali siswa membawa 3 botol bekas, dan 1 kardus bekas. Selain itu, background di buat semenarik dengan desain background APE dan mencetaknya di percetakkan.Sedangkan alat yang digunakan adalah cutter, lem tembak, cat pilok, penggaris, kertas kado/ kertas warna, spidol, kuas kecil.

\section{Tahap Pelaksanaan}

Pelaksanaan kegiatanpengabdian pemanfaatan botol dan kardus bekas dalam pembuatan alat peraga edukatif (ape) di gugus paud 10 kecamatan kanigaran probolinggo pada tanggal 5 desember 2018 bertempat di RA Al Hikmah. Adapun langkah pembuatan APE sebagai berikut.

a. Memotong kardus dan botol.

Pada tahap ini yang dilakukan adalah memotong kardus menjadi ukuran A3 sebanyak 4 buah, 3cm x $297 \mathrm{~cm}$ dan 3cm x 420cm sebanyak 20 buah. Selain itu juga memotong ujung botol berkisar $2-4 \mathrm{~cm}$ dari tutup botol.Selain itu juga memotong kertas desain sticker huruf alphabet dan huruf hijaiyah yang sudah di cetak.Adapun tampak gambar sebagai berikut. 


\section{INTEGRITAS : Jurnal Pengabdian}

Vol 3, No 1, Juli 2019

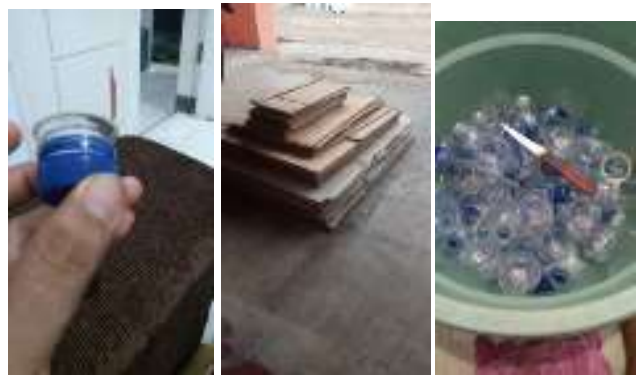

Gambar 1. Potongan botol dan potongan kardus

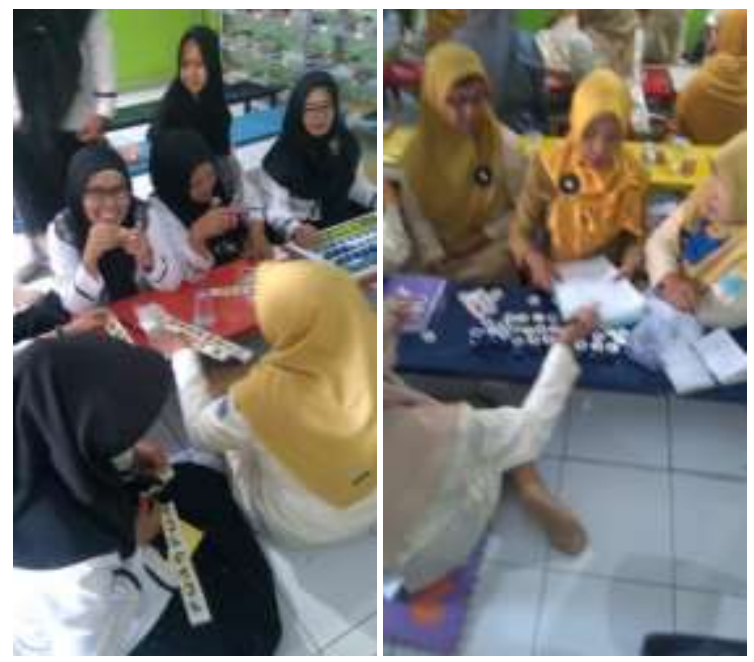

Gambar 2.Memotong sticker huruf alfabet dan huruf hijaiyah.

b. Membuat lubang pada background dan kardus

Langkah pertama pada tahap ini adalah melubangi background dengan menggunakan gunting, kemudian membuat lingkaran pada 2 buah kardus menggunakan spidol, kemudian 1 buah kardus tersebut dilubangi menggunakan cutter. Adapun gambar pada tahap ini sebagai berikut.

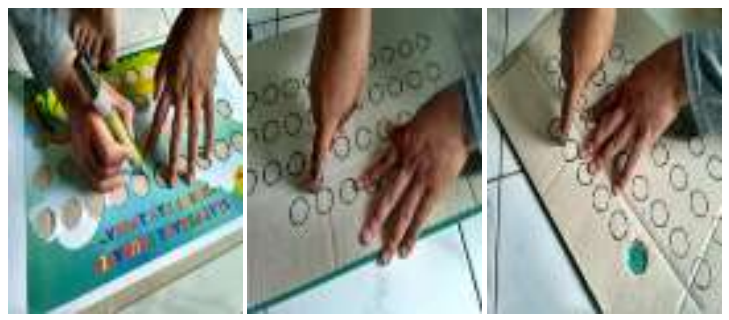

Gambar 3. Melubangi kardus 


\section{INTEGRITAS : Jurnal Pengabdian}

c. Mengecat tutup botol

Pada tahap ini, mengecat tutup botol dengan menggunakan cat pilok putih.Tujuan dari perlakuan ini adalah supaya hasil media lebih menarik dan bagus.

d. Memasang botol ke kardus

Setelah tutup botol kering, langkah selanjutnya adalah memasangkan botol pada kardus yang sudah dilubangi.Setelah semua botol terpasang pada kardus maka selanjutnya background juga di tempelkan pada kardus dengan menggunakan lem.Sedangkan bagian belakang kardus yang terpasang botol di beri lem tembak pada semua sisi botol.Hal ini dilakukan dengan tujuan saat memasang tutup botol, badan botol tidak ikut bergerak (paten).

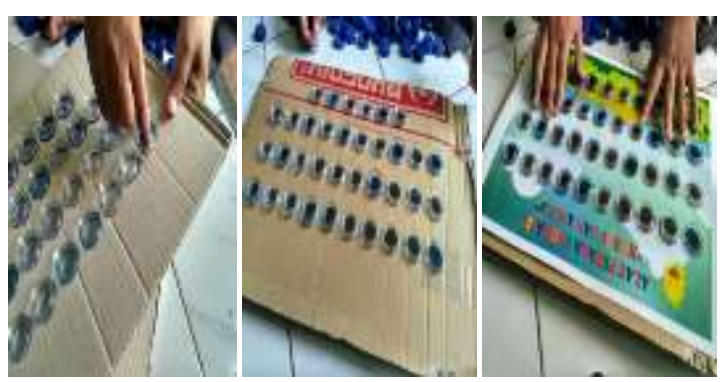

Gambar 4.Memasukkan botol kedalam kardus yang sudah dilubangi.

e. Membuat penutup kardus bagian belakang

Tahap selanjutnya adalah membuat bingkai belakang dan penutup kardus dengan menggunakan potongan kardus yang sudah disiapkan dan lem.Sebelum itu bagian penutup dipasang sticker huruf yang sudah disiapkan pada lingkaran yang sudah dibuat.Setelah diberi bingkai dan ditutup bagian belakang media APE, selanjutnya untuk memperindah tampilan, bagian kiri, kanan, atas dan bawah di pasang kertas warna dengan menggunakan lem. 


\section{INTEGRITAS : Jurnal Pengabdian}

Vol 3, No 1, Juli 2019

ISSN 2580-7978 (Cetak) ISSN 2615-0794 (Online)

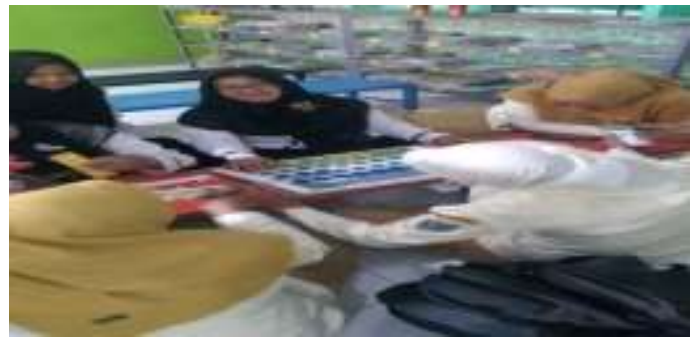

Gambar 5.Memasang penutup kardus bagian belakang.

f. Memasang sticker huruf alfabet dan huruf hijaiyah pada tutup botol.

Tahap terakhir adalah memasang sticker yang sudah disiapkan pada tutup botol.Kemudian dipasangkan pada badan botol sesuai dengan sticker huruf yang berada pada background APE yaitu dengan melihat pada lubang botol.

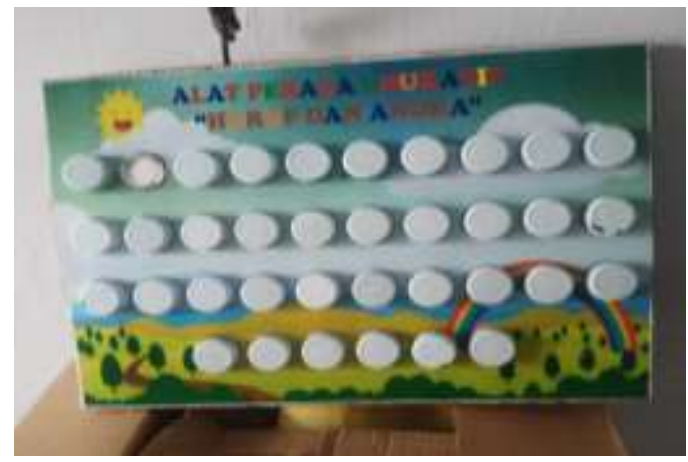

Gambar 6.Memasang tutup botol tanpa sticker huruf alfabet dan huruf hijaiyah.

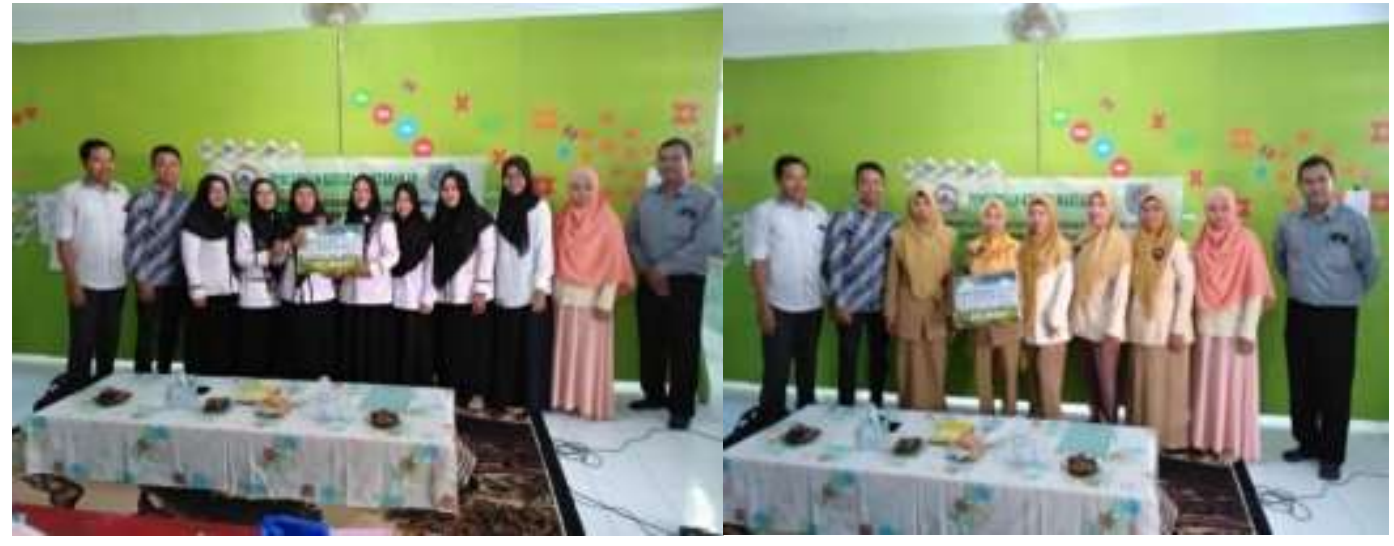

Gambar 7. Hasil akhir APE setelah pemasangan tutup botol dengan sticker alfabet dan hijaiyah. 


\section{INTEGRITAS : Jurnal Pengabdian}

Vol 3, No 1, Juli 2019

ISSN 2580-7978 (Cetak) ISSN 2615-0794 (Online)

\section{Tahap Evaluasi}

Setelah media APE dibuat, selanjutnya adalah uji coba cara penggunaan APE. APE ini digunakan saat pembelajaran mengenalkan huruf alphabet dan huruf hijaiyah.Adapun langkah-langkah penggunaan APE ini sebagai berikut.

a. Guru mengenalkan huruf dengan cara menunjuk huruf dan secara lisan menyampaikan hurufnya. Pada fase ini siswa melatih pendengaran, konsentrasi terhadap bentuk huruf dan nama huruf. Tujuan awal mengenalkan dan mengingat bentuk huruf Alfabet maupun huruf hijaiyah ke siswa.

b. Fase selanjutnya dengan bersama-sama siswa mengucapkan nama huruf berurut secara lantang. Pada fase ini setelah mengenal bentuknya, siswa diajak mengenal nama huruf. Kemudian diulang beberapa kali.

c. Tahap terakhir, siswa diajak bermain mencocokkan bentuk huruf alphabet maupun huruf hijaiyah. Caranya semua tutup botol dilepas semua dari batang botol. Kemudian guru meminta/ mendampingi bantuan siswa untuk memasangkan ke background APE. Siswa mencocokkan dengan cara melihat kedalam lubang botol. Setelah tepat siswa diminta untuk menyampaikan nama huruf tersebut.

d. Tahap terakhir, setelah melihat perkembangan siswa tentang mengenal huruf alphabet dan huruf hijaiyah. APE ini bisa digunakan oleh siswa didampingi guru dengan permainan kompetisi cepat memasang tutup botol huruf ke background APE sesuai dengan pasangan huruf alphabet maupun hijaiyah.

Adapun gambar saat penyampaian langkah penggunaan APE sebagai berikut.

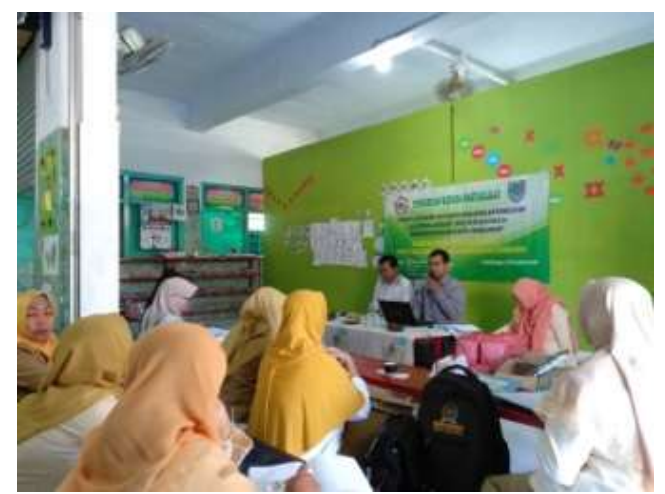

Gambar 8. Penyampain penggunaan APE Pengenalan huruf alfabet dan huruf hijaiyah 


\section{INTEGRITAS : Jurnal Pengabdian}

Vol 3, No 1, Juli 2019

ISSN 2580-7978 (Cetak) ISSN 2615-0794 (Online)

Dari langkah penggunaan tersebut, terlihat inovasi pengenalan huruf dan cara mengingat huruf tersebut. Kondisi yang terjadi saat pembelajaran siswa sangat menarik dan mneyenangkan.Disisi lain, aspek sasaran pembelajaran dengan menggunakan APE ini adalah aspek kognitif, fisik motorik, bahasa dan soisal emosional serta kemandirian.

\section{LUARAN YANG DICAPAI}

Adapun luaran PKM ini adalah sebagai berikut.

a. Media pengenalan huruf alfabet maupun hijaiyah.

b. Buku Panduan pembuatan karya APE Guru PAUD Gugus 10 Kecamatan Kanigaran Kabupaten Probolinggo.

c. Rangsangan terhadap guru supaya selalu mengembangkan kreatifitas dan inovatif pembelajaran dalam kelas sehingga nuansa pembelajaran selalu dinamis dan menarik. Dengan kata lain peningkatan kualitas kreatifitas dan inovatif guru meningkat.

d. Publikasi/ jurnal pengabdian.

\section{KESIMPULAN}

Dari kegiatan pengabdian ini dapat disimpulkan bahwa :

1. Pengadaan APE tidak harus bersifat konsumtif namun produktif lebih dianjurkan.

2. Peningkatkan kualitas guru dari segi kreatifitas dan inovasi pembelajaran.

3. Biaya yang digunakan jauh lebih ekonomis karena memanfaatkan barang bekas sebab merubahnya menjadi suatu barang yang ternilai dan bermanfaat sebagai media pembelajaran.

4. Kegiatan pembelajaran pengenalan huruf alfabet dan huruf hijaiyah lebih berwarna, menarik dan menyenangkan. 
INTEGRITAS : Jurnal Pengabdian

Vol 3, No 1, Juli 2019

ISSN 2580-7978 (Cetak) ISSN 2615-0794 (Online)

\section{REFERENSI}

Basyaruddin, Yosi, dan Abdillah Obid. 2004. Manhaj pendidikan Anak Muslim. Jakarta Selatan : Mustaqim.

https://www.alatperaga.web.id/product-category/alat-peraga-edukatif-paud/alatperaga-paud/

Ismail, Andang. 2007. Education Games: Menjadi Cerdas dan Ceria dengan Permainan Edukatif. Yogyakarta: Pilar Media.

Martuti, A. 2008.Mengelola PAUD dengan Aneka Permainan Meraih Kecerdasan Majemuk.Yogyakarta : Kreasi Wacana.

Permendiknas 58 tahun 2009.

Musbikin, Imam. 2006. Mendidik Anak Kreatif ala Einsten. Yogyakarta: Pustaka Pelajar. 